\title{
Imaging Findings of Nonketotic Hyperglycemia
}

\author{
Nonketotik Hiperglisemide Görüntüleme Bulguları
}

Ergul Cindemir, (D) Nurdan Gocgun, (D) Turkan Ikizceli, (D) Behice Kaniye Yilmaz, iD Rustu Turkay Istanbul Haseki Training and Research Hospital, Department of Radiology, Istanbul, Turkey.

\begin{abstract}
The globus pallidus and putamen are highly vascular structures, because of that, they are more sensitive to the metabolic changes in the brain. In the evaluation of nonketotic hyperglycemia and differential diagnosis with imaging findings is in the globus pallidus and nucleus caudatus usually symmetrically and bilaterally but rarely unilaterally hyperattenuating on non-enhanced computed tomography (NECT) and hyperintensity on T1-weighted magnetic resonance images (MRI) have been reported. In this report, we aimed to present poorly controlled diabetic patients that have been admitted to the emergency service with uncontrolled movements defined as chorea.

ÖZET

Globus pallidus ve putamen, beyindeki metabolik değișikliklere duyarlı hipervasküler yapılardır. Nonketotik hipergliseminin değerlendirilmesinde ve görüntüleme bulgulart ile ayırıc tanıda kontrastsı beyin bilgisayarl tomografide (BBT) globus pallidus ve nukleus kaudatus da genellikle simetrik ve bilateral ancak nadiren tek taraflı hiperatenüasyon ve $T 1$ ağırlıkl manyetik rezonans görüntülerde (MRG) bu alanlarda hiperintensite artış izlenmektedir. Bu yazıda acil servise kore olarak tanımlanan kontrolsüz hareketlerle başvuran diyabetik hastaların görüntüleme bulgularını sunmayı amaçladık.
\end{abstract}

\section{Keywords:}

Nonketotic hyperglycemia,

Chorea,

Stroke mimickers,

Magnetic resonance imaging.

Anahtar Kelimeler:

Nonketotik hiperglisemi,

Kore,

Stroke taklitçileri,

Manyetik rezonans görüntüleme.

\section{INTRODUCTION}

Deep gray matter structures such as the thalamus and the basal ganglia are highly metabolically active. In various pathologic conditions like metabolic abnormalities, toxic poisoning, and neurodegeneration of the brain with iron accumulation, these structures are affected usually symmetrically and bilaterally (1). Nonketotic hyperglycemia has been associated with a characteristic appearance in the basal ganglia usually bilaterally but rarely unilaterally hyperattenuating on non-enhanced computed tomography (NECT) and hyperintensity on T1-weighted magnetic resonance images (MRI) (2). If symptoms are unilateral, the imaging findings will be typically contralateral to the symptomatic bodyside (3).

\section{CASE}

A 61-year-old female presented to the emergency service with uncontrolled movements defined as chorea. Her medical history includes poorly controlled diabetes mellitus. NECT was performed in the emergency department with a 128 detector CT scanner (PHILIPS Ingenuity, Nederland) and MRI was performed with a 1.5T MR Scanner (GEM flex LG full, USA).

NECT showed hyperdensity within the right caudate nuclei and lentiform nucleus (figure 1). Acute infarction was excluded because diffusion restriction was not observed on diffusion-weighted images (DWI). Control MRI revealed hyperintensity on T1WI (figure 2) and slightly hypointensity on T2WI (figure 3) within the right caudate nuclei and lentiform nucleus. Gradient echo images showed normal signal intensity in these areas (figure 4), so hemorrhage was excluded. And in the basal ganglia, T2 prolongation was not observed because of that acute toxic poisoning and metabolic abnormalities were also excluded. With the clinical history, we defined the lesions as nonketotic hyperglycemia.

\section{DISCUSSION}

The caudate nucleus and the lentiform nucleus are symmetrically located between the lateral ventricles and are isointense compared to the cortical gray matter in all sequences on MRI. The globus pallidus and putamen are highly vascular structures, because of that, they are more sensitive to the metabolic changes in the brain and also generalized and systemic disease (1).

NECT typically shows symmetrically and bilaterally but rarely unilaterally hyperattenuating on the basal ganglia. At MRI, T2WI are usually hypointense and variable but on T1WI these areas are characteristically hyperintense. The mechanism is unknown but some hypothesis have been reported, the most commonly accepted hypothesis is that the signal abnormality represents putaminal petechial hemorrhage (4). Some case series have reported that diffusion restriction may be seen in these areas $(2,3)$. Gradient echo imaging is important to exclude parenchymal hemorrhage or hemorrhagic

Correspondence: Ergul Cindemir, Istanbul Haseki Training and Research Hospital, Department of Radiology, Istanbul, Turkey. Email: ergulkahraman@yahoo.com.

Cite this article as: Cindemir E, Gocgun N, Ikizceli T, Yilmaz BK, Turkay R. Imaging Findings of Nonketotic Hyperglycemia. Phnx Med J. 2020;2(3):175-177. 


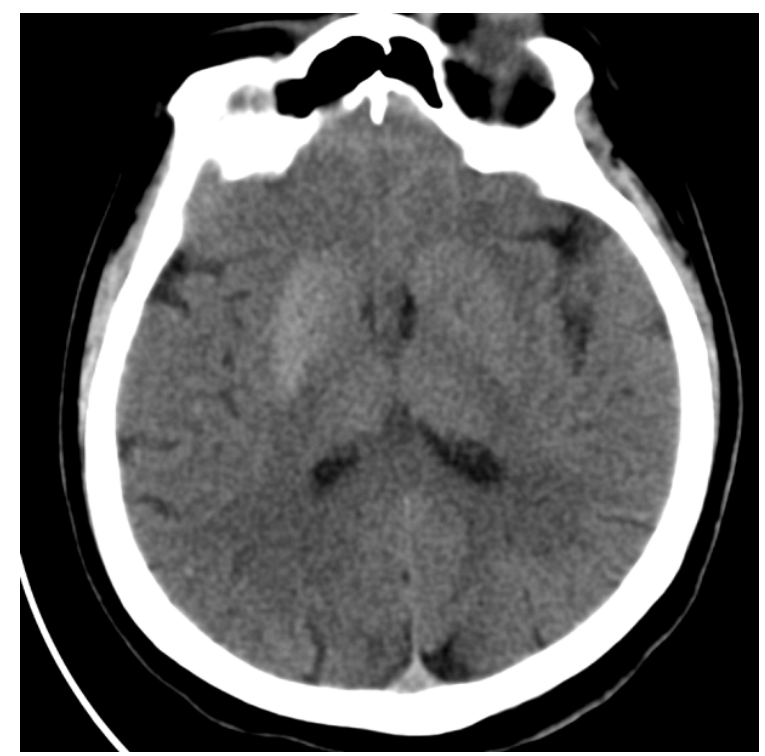

Figure 1: Non-enhanced axial CT imaging reveals hyperdensity within the right caudate nuclei and lentiform nucleus.

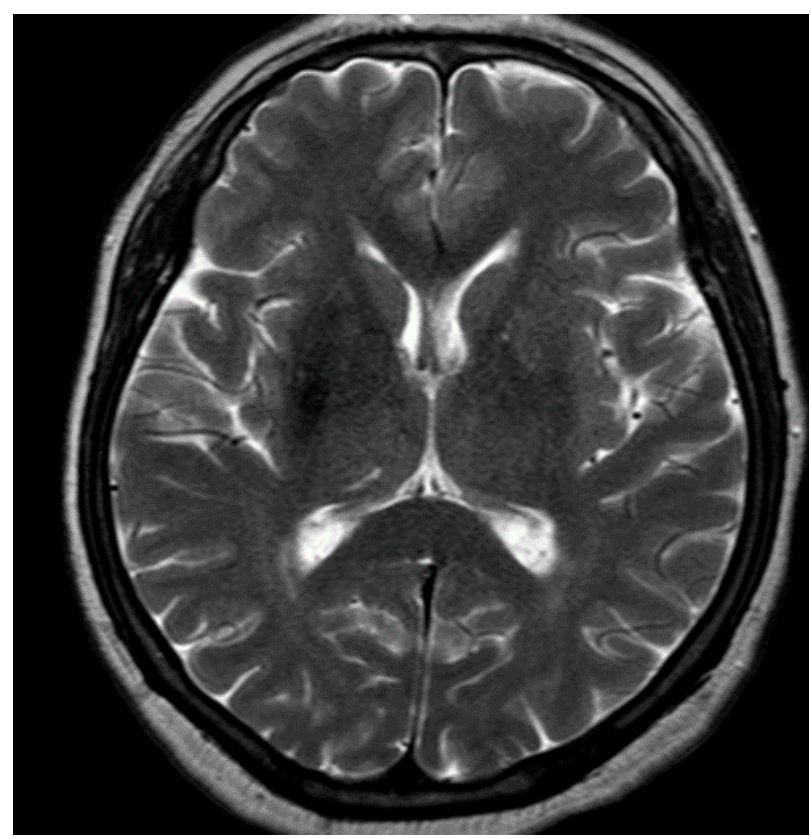

Figure 3: Axial T2 weighted MRI shows the abnormal area is slightly hypointense.

infarct. The other hypothesis is the deposition of some minerals like calcium, proteins, and myelin breakdown products $(1,2)$. Besides knowing the clinical history of a patient, imaging findings are diagnostic. MRI is the modality that must be selected for the final diagnosis but NECT may be the first choice, especially in emergencies.

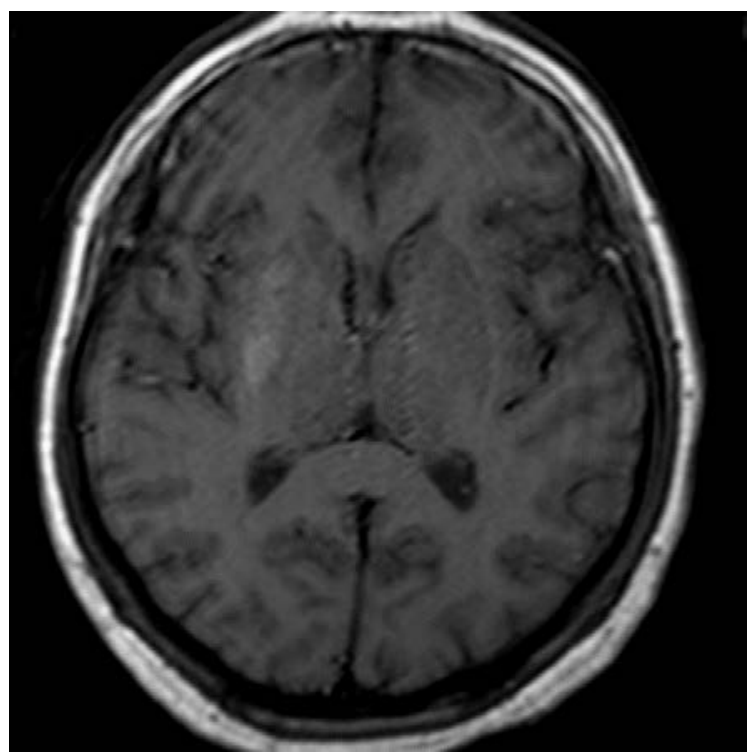

Figure 2: Non-enhanced T1 weighted MRI reveals hyperintensity within the right caudate nuclei and lentiform nucleus.

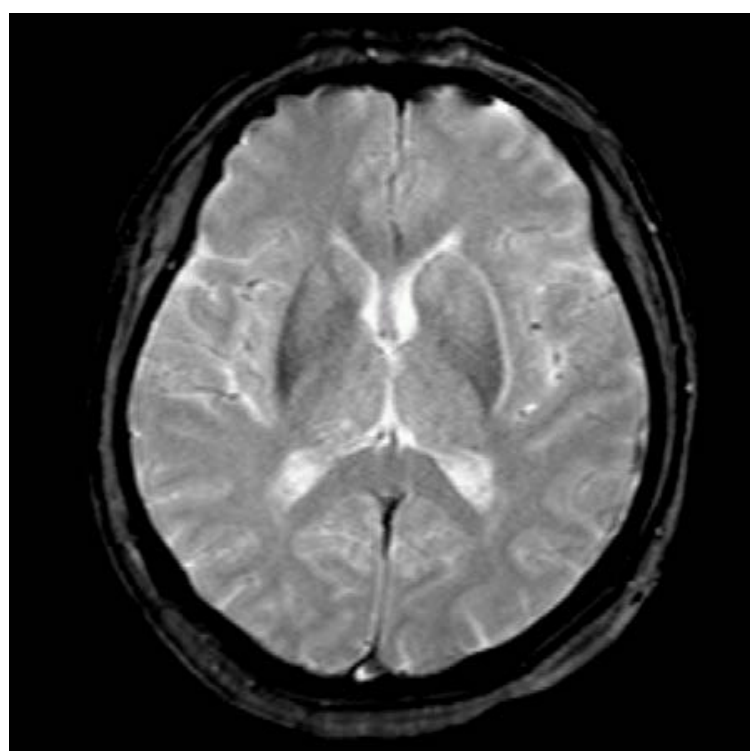

Figure 4: Axial gradient-echo MRI revealed that the right caudate nuclei and the lentiform nucleus are normal because of this parenchymal hemorrhage or hemorrhagic infarct is excluded.

Conclusion: Although nonketotic hyperglycemia mimics stroke, in poorly controlled diabetic patients who present with acute chorea, and sometimes mental deterioration have typically imaging findings such as hyperdense/hyperintense putamen and/or caudate nucleus contralateral to the side of the patient's symptoms should be diagnostic on both NECT and T1 weighted MRI.

Conflicts of Interest

The authors have no conflicts of interest to declare. 
Phnx Med J. November, 2020. Volume 2 No 3

\section{REFERENCES}

1. Hegde AN, Mohan S, Lath N, Lim CCT. Differential Diagnosis for Bilateral Abnormalities of the Basal Ganglia and Thalamus. RadioGraphics, 2011;31(1): 5-30.

2. Hansford BG, Albert D, Yang E. Classic neuroimaging findings of nonketotic hyperglycemia on computed tomography and magnetic resonance imaging with absence of typical movement disorder symptoms (hemichorea-hemiballism). Journey of Radiology case reports. 2013;7(8):1-9.

3. Wintermark M, Fischbein NJ, Mukherjee P, Yuh EL, Dillon WP. Unilateral putaminal CT, MR, and diffusion abnormalities secondary to nonketotic hyperglycemia in the setting of acute neurologic symptoms mimicking stroke. AJNR Am J Neuroradiol. 2004;25(6):975-976.

4. Shan DE, Ho DM, Chang C, Pan HC,Teng MM. Hemichorea-hemiballism: an explanation for MR signal changes. AJNR Am J Neuroradiol 1998;19:863-870. 